Northwestern University School of Law Northwestern University School of Law Scholarly Commons

Faculty Working Papers

1981

\title{
Lon Fuller and Substantive Natural Law
}

Anthony D'Amato

Northwestern University School of Law, a-damato@law.northwestern.edu

\section{Repository Citation}

D'Amato, Anthony, "Lon Fuller and Substantive Natural Law" (1981). Faculty Working Papers. Paper 131.

http://scholarlycommons.law.northwestern.edu/facultyworkingpapers/131 


\title{
Lon Fuller and Substantive Natural Law, by Anthony D'Amato,* \\ 26 Am. J. Juris 202-218 (1981)
}

\begin{abstract}
I will contend that Fuller's secular or "procedural" natural law, as described by Moffat, does not cover the theoretical position that could be occupied by a substantive natural lawyer, that such a theoretical position is viable today, and that there are some key elements in Fuller's theory that actually conflict with substantive natural law and might therefore be criticized from that perspective.
\end{abstract}

Tags: Jurisprudence, Natural Law, Fuller (Lon), Hart, Dworkin, Cicero, Bentham, Austin, Aquinas

[pg202]** Since Lon Fuller was the efficient, sufficient, and necessary cause of my entering the field of jurisprudence, it is with some trepidation that I venture here to criticize his work. However, I take a little comfort from the fact that he always welcomed criticism, even from, and sometimes particularly from, the converted.

I will contend that Fuller's secular or "procedural" natural law, as described by Professor Moffat, does not cover the theoretical position that could be occupied by a substantive natural lawyer, that such a theoretical position is viable today, and that there are some key elements in Fuller's theory that actually conflict with substantive natural law and might therefore be criticized from that perspective. The following chart indicates that my criticism will come from the "right wing." For the most part, Fuller's critics have come from the left, and I remember the rather bemused-amused look on his face when he talked about how hospitable various Catholic theologians and Jesuits were to his writings - the point was that maybe their hospitality grew out of some misconceptions about what he was actually saying. (Interestingly enough, though it is a point I will not pursue here, I have an impression that in the past decade leading Catholic thought has moved leftward towards Fuller's actual position!)

\begin{tabular}{|c|l|l|l|l|l|}
\hline \multicolumn{7}{|c|}{ A CRUDE TABULAR VIEW } \\
OF SOME SELECTED LEGAL THEORISTS \\
\hline $\begin{array}{c}\text { Bentham, } \\
\text { Austin }\end{array}$ & \multicolumn{1}{|c|}{ Hart } & \multicolumn{1}{|c|}{ Dworkin } & \multicolumn{1}{c|}{ Fuller } & \multicolumn{1}{c|}{ Aquinas } & \multicolumn{1}{c|}{ Cicero } \\
\hline $\begin{array}{l}\text { No necessary } \\
\text { connection } \\
\text { between law and } \\
\text { morality. }\end{array}$ & $\begin{array}{l}\text { No necessary } \\
\text { connection but } \\
\text { morality } \\
\text { influences law } \\
\text { over a period of } \\
\text { time. }\end{array}$ & $\begin{array}{l}\text { A kind of } \\
\text { morality in the } \\
\text { concepts of } \\
\text { freedom and } \\
\text { equal respect for } \\
\text { persons, which } \\
\text { are connected to } \\
\text { law (or perhaps } \\
\text { to the U.S. } \\
\text { Constitution) }\end{array}$ & $\begin{array}{l}\text { Order, } \\
\text { coherence and } \\
\text { clarity have an } \\
\text { affinity with } \\
\text { goodness and } \\
\text { morality. }\end{array}$ & $\begin{array}{l}\text { Law and } \\
\text { morality are } \\
\text { parallel to each } \\
\text { other. They are } \\
\text { two ways of } \\
\text { looking at the } \\
\text { same rules. }\end{array}$ & $\begin{array}{l}\text { There is a } \\
\text { necessary } \\
\text { connection } \\
\text { between law and } \\
\text { morality. }\end{array}$ \\
\hline
\end{tabular}


[pg203] Fuller always maintained that the calling-card of a positivist was an insistence that law has no necessary connection with morality,FN1 and the above chart reflects my agreement with this observation. Bentham argued that the tendency to confuse morality and law was what made the common law so reactionary and blind to social progress.FN2 Hart is only slightly less critical; he allows that morality does accompany law over time as a historical, but not as a necessary, obliggato.FN3 Dworkin does not really attack positivism on this central issue, and hence I place him still to the left of center.FN4 Dworkin seems to attribute moral dimensions to the notions of freedom and of equal respect for persons, from which standpoint he criticizes various legal issues, but it is not clear to me whether he considers his critique as valid generally or only as a specific interpretation of the U.S. Constitution.FN5 In contrast, Fuller includes any and all legal systems in his observation that order, coherence, and clarity have an affinity with morality.FN6 Fuller is not clear whether he means that this affinity is a matter of historical observation (and thus somewhat like Hart's concept) or a matter of necessity; I think he probably meant it was both. But even so, he is talking about the "internal morality of law" and on that point he differs from the right wing. Cicero regarded morality and law necessarily connected as to specific substantive obligations.FN7 True laws, according to Cicero, were those laws consistent with justice and natural law; if a law duly enacted was inconsistent with justice or morality, then it was a law in name only, not deserving of the title "law" any more than a harmful chemical packaged a non-druggist was entitled to be called a "prescription."FN8 Nor is this a mere verbal dispute, since citizens and judges only have an obligation to obey true laws; they have no obligation to obey the other kind which are only commands that might equally issue from a gang of thieves as from the government.

The position that Fuller staked out for himself on the jurisprudential spectrum was at least politically astute. To his right were [pg204] Catholics and antiquarians steeped in normative universalist theories. Fuller could play it as close to the center as possible and still have the entire right-half of the chart for himself. Moreover, in this century, positivism in legal philosophy like positivism in philosophy and in the sciences has seemed to be scientific, rational, empirical, and precise. Fuller did battle with critics on his left by using the same valuefree terms as they, by appearing neutral and unbiased even as he brilliantly unmasked the deep antirationalism of Austin and Kelsen.FN9 Moreover, had he moved to the right, he probably would have been associated with Roman Catholicism, Crusades, Inquisitions, and infallible popes - not the best company for a legal theorist in the mid-twentieth century. More fundamentally, I believe Fuller was somewhat a prisoner of the age of relativism. The public believed that Einstein showed that everything was relative (nothing could be farther from the truth; Einstein constructed his entire theory upon a universal absolute, the speed of light).FN10 Anthropologists in the early and mid-twentieth century were instructing generations of college students and through them the public as a whole that morality is relative, varying from culture to culture, and we must be tolerant of people whose values are very different from our own.FN11 And in legal theory the search has been for neutral principles to which no one could take offense.FN12 The pseudo-scientific rationalism of the positivists combined with the cynicism of the legal realists to instruct generations of law students not only that there are two sides to every issue but that both sides are equally arguable, reasonable, and (as far as anyone can ever tell) equally right. 
In contrast, the substantive natural law position holds that some things are right for all times and all places, other things are always wrong, and two reasonable people could not differ about which was which because if they differed then one of them would not be reasonable. Because this position seems unscientific, and because it not only seems but is universalistic, absolutistic, and arrogant, the burden is on me to explain why it is a defensible position and ought to be taken seriously. I will try to do this by way of linguistic analysis and some comments about cultural anthropology.

[pg205] Let me start with two stipulated definitions. I will define morality-one (M-l) as that morality which you, the reader and observer for the purpose of this discussion, consider universally valid. For example, I believe you would condemn at any time and any place the deliberate infliction of severe pain upon an innocent child or the deliberate killing of a person for the killer's own personal profit. Let me define morality-two (M-2) as relative morality, that is, something which you might label as immoral in some societies and places and moral in others. For example, I would guess that you might consider extramarital sexual intercourse among consenting adults as not contrary to the morality of the city you are living in today, but you might consider it contrary to the morality of that city a hundred years ago. And even if I am not right in these guesses, I think I can safely predict that you would not consider extramarital sexual intercourse to be immoral among the Pueblos of New Mexico as reported by anthropologist Ruth BenedictFN13 or the teenagers of Samoa as reported by Margaret Mead.FN14

Now let us look more closely at M-2. If you the observer can say of practice $\mathrm{X}$ that it is moral in society A but immoral in society B, do you conclude for yourself that the morality of $\mathrm{X}$ is relative to the society in which it occurs? We have many examples of customs and mores that are relative to their societies: it is a breach of etiquette to eat with one's fingers in this country and a breach of etiquette not to do so in some other countries; fifty years ago a gentleman was expected to open a door for a lady, today some women consider such action to be a sign of male chauvinism. I think it's safe to conclude. that you do not consider any of these variable customs or mores to be, for you, matters of "morality." But now what about extramarital sexual intercourse? If you believe that it is moral in some places and times and immoral in others, then for you it is a matter of M-2. But now I want to make a stronger conclusion. I would argue that any example you come up with of M-2 is not for you a matter of morality at all. I do not believe that if you can truly countenance behavior $\mathrm{X}$ as right for some societies and places, while holding it to be wrong for other societies or places, that you are talking about "morality" at all. At best, you are describing what other people may call act X. In short, M-2 is "custom" or "mores" and not "morality."

If now we turn to M-l and any list of examples of it you might care to make, such as murder or child abuse, I believe you would condemn it wherever or whenever it occurs.FN15 You would indeed feel an inner [pg206] compulsion to intervene to prevent a child from being tortured, for instance, or you might call third persons or the police or speak up and at least try to convince the actor to cease and desist. These same internal feelings of an urge to intervene or to condemn cannot rationally be present if the time or the place of the act makes all the difference to you - that is, if your attitude is "when in Rome, do as the Romans do." An analogy might be the way we treat one case as precedent for another. If we say that a previous case is "on all 
fours" with a current case, we omit differences such as the fact that the previous case took place at an earlier time, or that there were different parties to that case, or that, although it occurred in the same legal jurisdiction as the current case, the facts of that case occurred three miles away from the facts of the present case. A true precedent is like a moral judgment. Although we might call extramarital sexual intercourse a matter of "morality," and although I provisionally labelled it M-2 to reflect this popular nomenclature, in fact practices that we tolerate as relative to a particular society are not for us moral practices at all. The point is put this way by Professor William Frankena:

\begin{abstract}
Suppose I go to Jones for advice about what to do in situation Y, and he tells me that I morally ought to do Z. Suppose I also recall that the day before he had maintained that $\mathrm{W}$ was the right thing for Smith to do in a situation of the same kind. I shall then certainly point this out to Jones and ask him if he is not being inconsistent. Now suppose that Jones does not do anything to show that the two cases are different, but simply says, "No, there is no connection between the two cases. Sure, they are alike, but one was yesterday and involved Smith. Now it’s today and you are involved." Surely, this would strike us as an odd response from anyone who purports to be taking the moral point of view or giving moral advice. The fact is that when one makes a moral judgment in a particular situation, one implicitly commits oneself to making the same judgment in any similar situation, even if the second situation occurs at a different time or place, or involves another agent.FN16
\end{abstract}

[pg207] But why then do we hear so much about moral relativism if the conclusion I have reached is valid, namely, that the term "moral" in "moral relativism" is an incorrect and misleading use of that term? I believe that the answer is that the famous cultural anthropologists of the early and mid-twentieth century, such as William Graham Sumner, Raymond Firth, Ruth Benedict, Kroeber and Kluckhohn, and Margaret Mead, through their studies of remote, primitive, or isolated cultures, were surprisingly successful in teaching college students and the general public that morality is relative to a particular culture and hence we should be tolerant of other values. Ruth Benedict writes, for example, "We recognize that morality differs in every society, and is a convenient term for socially approved habits."FN17 And in a different book, she calls upon us to get rid of our cultural ethnocentrism, and to tolerate not only the behavior of people in other societies but also the abnormal behavior of persons in our own society.FN18 "Moral" relativism thus becomes a plea for tolerance, a plea that in our time falls upon receptive ears.

The trouble with the anthropologists' theories is that they all generalize from a single example: extramarital sexual intercourse. This is the practice they find in other societies that they label as immoral in our view but moral for those societies, and then conclude that we should be tolerant of behavior we consider immoral because the people who engage in that behavior probably consider it moral. But as the philosopher John Cook has found after studying the anthropologists' writings, there are no other examples that they adduce of this moral relativism.FN19 To be sure they find folkways, mores, and customs different in different societies, but we do not label any of those behaviors "immoral." And when they find things that we consider immoral, it turns out on considered examination that all the other societies consider them as immoral also. To be sure, we sometimes have to look below the surface. A primitive society that engages in human sacrifice to appease the rain god might superficially be thought of as condoning murder. But if we examine what those people believe - that this is the only way to bring rain, and that rain is necessary to avert mass starvation from crop failure, then the sacrifice, no matter how absurd or superstitious it looks to us, is not murder. A parallel might be 
if aliens from another galaxy land on [pg208] Earth and accuse all of us of murder because our society condones capital punishment. We sometimes hear opponents of capital punishment say that "we are all murderers," and this is an attention-getting use of the term, but I don't think anyone seriously means that every adult in the United States should be locked in prison for the rest of his or her life because of this accusation. What we would say to the visitors from another galaxy is that we condone capital punishment out of the belief that murder will be deterred and thus fewer people will die than if we did not execute murderers. To the aliens, this may not sound any more scientific than human sacrifice to bring rain, but it does not mean that the society as a whole has committed "murder" in the moral sense that each member of the society should be severely punished therefor.

Perhaps the reason the anthropologists were able to get away with such a huge generalization based on the single case of extramarital sexual intercourse practices among the cultures they examined is that American society in the early and mid-twentieth century largely believed that such practices were immoral. The anthropologists, in fact, were a potent factor in convincing the public that extramarital sexual intercourse is not immoral. They might have done this simply by saying, in effect, see, other societies do these things all the time and nobody gets hurt and people seem to get along very well and therefore you should re-examine the Puritanical standards in the United States. But that was not the academic way of theorizing. So instead they argued that all morality is relative to particular societies, and that sexual immorality is a very interesting example of this general thesis. Their conclusion got across to college students - namely, that extra-marital sex should not be taboo. But their reasoning has plagued us since with M-2 which, as I have argued, is not really "morality" at all.

Substantive natural law is founded upon a universal morality, or M-1. It is not a matter of over-theorizing or verbal imprecision. The substantive natural law position says that human beings living in society have certain innate rights and obligations. Among the things prohibited are murder, torture, theft, cheating, or the violation of any laws that are tied into, and a part of, a regime of justice. There is no tolerance for people who act on different opinions about these standards; far from expressing tolerance, the natural law advocate will insist that if persons act upon their different standards - for instance, commit murder - they should be punished for their acts. This is not a neutral or value-free philosophy, and it may very well be viewed as arrogant or old fashioned. Additionally, it is a philosophy that views itself as prior to the legal system and a restraint upon that legal system. In that sense it is quite undemocratic, in that it recognizes that [pg209] legislative majorities may pass laws that contradict the natural law.FN20 Under Cicero's view, "these no more deserve to be called laws than the rules a band of robbers might pass in their assembly."FN21 Hence, in his view, people should not obey them (and if people do, it is only because they are being coerced—Hart's "gunman" situation).FN22 Finally, natural law would enforce some rules as part of the legal system even if no statutes were ever passed making them laws. Cicero's example is the rape of Lucretia. The rape was illegal, he writes, "even if there was no written law against rape in Rome" at that time.FN23

Fuller's philosophy sharply departs from natural law on such matters. In his basic formulation of the "internal morality of law," Fuller writes that "certainly there can be no rational grounds for asserting that a man can have a moral obligation to obey a legal rule that does not exist, or is kept secret from him, or that came into existence only after he had acted.... 
FN24 But Cicero's rape example contravenes Fuller directly. Or what if a legislature fails to renew a criminal code after its expiration date as set by a previous legislature? Then many [pg210] criminal rules would "not exist," in Fuller's terms, but they would continue to exist under a natural law view of the legal system. And how would Fuller deal with common law crimes? To be sure, Fuller's description of common law is one of the best contributions he has made,FN25 and yet the very first case involving a new crime that nevertheless violates natural law would pose a difficult problem for Fuller in light of his strictures on the "internal morality of law." So too would the Nuremberg trials.FN26 There, the Nazi defendants pleaded that there was no law and hence they should not be punished, and though international lawyers can and have shown that international rules proscribing the defendants' actions did exist, one can hardly say of those rules that they fitted Fuller's eight conceptions of what constitute the internal morality of law. Finally, Fuller's very use of the term "morality" in his concept of the "internal morality of law" tends to throw us off, because he seems to be pitting one kind of morality (procedural) against another (substantive).FN27 We begin to suspect that Fuller has used the term "morality" the way I have defined M-2, as an honorific title and not really a matter of morality at all.

I would like to develop my contention of moral relativism in Fuller's work by reference to a different, though also central, thesis of his. I will use an extended example given by Fuller in his essay "Reason and Fiat in Case Law,"FN28 which he regarded as one of the two most succinct statements of his philosophy.FN29 In that essay he asks us to imagine a group of shipwrecked men on an isolated island. We also imagine that each man has been visited by an amnesia that has wiped out all memories of previous social existence and laws and conventions_an idea rather like Rawls' "original position" in A Theory of Justice FN30 which came out twenty-five years after Fuller's essay. Disputes arise and the group selects one of their number to be a judge or arbitrator for all controversies. The question is, what standards does he use when there are no rules or laws on the books and no one remembers anything of life before landing on the island?

[pg211] Fuller replies that such a judge or arbitrator will make his decisions conform to the group's purpose and goals. He will know that his decisions will come to be looked on as precedents, and hence can foresee that there would emerge from his decisions a body of rules that will both conform to the needs of the group and help shape the group's behavior. In short, he will believe, and will be justified in believing, "that there are external criteria, found in the conditions required for successful group living, that furnish some standard against which the rightness of his decisions should be measured."FN31 These standards, Fuller says, reflect "natural law," although Fuller adds that the term "still has about it a rich, deep odor of the witches' caldron, and the mere mention of it suffices to unloose a torrent of emotions and fears."FN32

But, we may ask, are these "external criteria found in the conditions required for successful group living" really "natural law"? Suppose one day the judge or arbitrator is informed that two of the men in the community of, say, thirty-three, were discovered by separate eyewitnesses as engaging in homosexual practices. The judge says, "What of it?" and the informers reply that naturally the two men must be executed swiftly and silently, lest their behavior "spread" and "infect and ultimately destroy" the rest of the community. The judge, 
shocked to hear this, duly sets about conversing, one at a time, with every member of the group except the two accused persons, and finds that all thirty of the men he talks with share the deep and passionate conviction that homosexuals should be immediately executed.FN33 What should the judge decide when faced with uncontrovertible evidence of homosexual practice and with unanimity among the rest of the group that the behavior should be met with summary execution? There is nothing in Fuller's account of law making in this community, even though he labels it "natural law," that I can see the judge could [pg212] evoke to avoid such an extreme penalty. The members of the group want the homosexuals to be executed, they desire it for the preservation of the group and its values as they understand those values, and they are perfectly ready to accept that decision as a precedent for any future cases of homosexuality. Moreover, even if we include into the equation all of Fuller's strictures in his later book The Morality of LawFN34 about the "inner morality of law," having to do with clarity, generality, conformity of rule to administrative action, avoidance of inconsistency or impossibility, and so forth, we still find no way for the judge to say that he cannot condone such a harsh penalty for an act of free choice on the part of two men in the group. Not only do I find nothing in Fuller's philosophy to prevent the judge from conforming his decision to the purposes and goals of the group, which in this case means to order the execution of the two homosexuals, but also Fuller's philosophy seems to require it. And more importantly, it would be particularly difficult for the judge in my hypothetical to try to invoke a different philosophy - that of natural law - even if he wanted to combat Fuller's. That particular difficulty arises from [pg213] Fuller's own invocation of the terms "natural" and "morality" to support and give extra weight to his philosophy, leaving our poor judge - assuming he does not want to execute the homosexuals — to say feebly, "but I don't mean that kind of 'natural law' or that kind of 'morality,"' The members of his group might be rather impatient with what to them might appear the judge's verbal quibbling with the eminent philosopher Lon Fuller. It's much easier for them and for the reader to think that Fuller was using the term "morality" in the standard way, just as many readers of Ruth Benedict found it much easier, and more interesting, to accept without much thought her invocation of the same term. For to think of Fuller and Benedict as simply meaning M-2 is almost to rob their writing of its force and power-even though such a step would promote clarity.

I find throughout Fuller's philosophy the recurrent notion that if we sufficiently take into account a society's purposes, aspirations, common needs, and goals, we can achieve a complete account, understanding, and specification of its laws. The proper construction of any statute, according to Fuller, rests upon an appreciation of these shared purposes. The important element that I find missing from Fuller's philosophy is that sometimes shared purposes are not enough if the group itself is committing an immoral act. The act, to my mind, does not have to be as blatant as executing homosexuals; equally invalid would be Justice Chase's example of a legislature taking A's property away and giving it to B.FN35 Or more recently, Nazi persecution of minorities would illustrate the point. It does not matter to me that the greatest good of the greatest number might be served by any of these three examples.FN36 But I suspect that utilitarianism, which certainly can be contrary to the rights of individuals as well as to substantive natural law in general,FN37 tends to color Fuller's philosophy just as deeply as it more explicitly colors the philosophies of the positivists whom Fuller attacked. Utilitarianism is a comfortable bedfellow with moral relativism, for both are not rooted in any particular normative vision of human nature but are rather free-floating systems whose content can totally change from one society to another.FN38 
[pg214] But even if there is relativity in Fuller's vision of common purpose in a given society, that fact should not obscure the significance of Fuller's quest for normative standards for the interpretation of law. He understood, as many contemporary writers do not, that "natural law" is by no means a mere circumlocution for procedural or substantive morality, but rather indicates a process of legal interpretation that fuses the normative with the descriptive or empirical analysis of law. To invoke the idea of "natural law" is to be saying something about existing law, and not about some other normative system divorced from law or in parallel to the legal system.FN39 It is thus somewhat disappointing to see in Robert Cover's important book Justice AccusedFN40 an easy equation of "natural law" with a substantive moral position (that slavery is immoral),FN41 followed by his derogatory references to the "natural law idiom"FN42 and his uneasy conclusion that positivism won't work and something else is needed (but by then he cannot advocate "natural law").FN43

Professor Cover missed an opportunity in his book to apply natural law precisely to the problem that he dealt with extensively - Northern judges faced with the issue of returning fugitive slaves back to their "owners" in the South. This issue arose in many contexts, notably the legal obligation of a magistrate or judge to send back a fugitive slaveFN44 and the question of civil damages for harboring a fugitive slave under the Act of Congress of 1793.FN45 In my opinion, a natural law analysis would say that whatever the legal relation might be between slave and owner on the latter's property (a relation which might arguably depend largely on how the servitude came into being and whether the [pg215] ongoing relationship was humane), a different situation arises when the slave has escaped. At that point, does the slave have an obligation to go back? To assert both that the slave has an obligation to return, and that the slave has no moral rights vis-a-vis the owner since he is merely the owner's chattel, is to assert an inconsistency. We cannot posit that the slave has moral duties if we also say that he is not a moral being. Hence I would conclude that it is incoherent to assert that the slave has an obligation to return, for at this point of escape the slave is no longer a "slave"—in Kantian terms, he is not a means but an end. It follows, I would argue, that others have no obligation to restore the fugitive to slave-status. Indeed, their obligation is the opposite: they should help the fugitive in his efforts to evade the owner's attempts to get him back.

But if this reasoning is accepted, the key question arises: what sort of "obligation" is it? A positivist would say that it is only a moral obligation; the "legal obligation" is the opposite. One might very well imagine H.L.A. Hart saying that a magistrate's moral obligation not to return the slave fugitive supersedes his legal obligation to send the slave back, with the conclusion that the magistrate should resign from office rather than doing an immoral act.FN46 Professor Cover refers repeatedly to the resignation alternative and also ventures into psychological speculation concerning the moral dilemmas and cognitive dissonance experienced by judges who faced these conflicting moral and legal obligations.FN47 His position is clearly that of a positivist who views law and morality as separate,FN48 despite his discomfiture with "positivism."FN49 But all this, as Professor Fuller might have said, points to the deep trouble with positivism as a legal theory. For the natural law position, in contrast, would say that there is no such things as "legal obligation" apart from moral obligation. Statutory law and constitutional law do not give rise to an "obligation" unless their dictates are congruent with moral imperatives, and then only because of the congruence. I do not have an 
"obligation" to obey an immoral law; at best it might only be prudent for me to do so (i.e., the gunman or the state - as gunman writ large - might shoot me if I didn't).FN50 Hence we must interpret statutory and constitutional law [pg216] in light of their necessary connection, as "law," with natural law. Part of the necessity of that connection, as I tried to show in a previous article, comes through the person of the judge as a moral agent and a necessary participant in the legal process.FN51 Another part comes in the strict construction of the statute or Constitution to avoid an moral result. Notably there were many ingenious attempts at doing precisely this in the nineteenth century, but Professor Cover, trapped by his own perspective, dismisses these as the illusions of libertarians.FN52 Quite the contrary, the exegesis of statutes and the Constitution to avoid sending the slave back was, I believe, the essence of the natural law approach.FN53 One only had to take a class with Professor Fuller to see how peerless he was in engaging in such methodology. The law, to him, was a lot more complex than it might appear on the surface, and when moral issues were at stake, a patient examination and unfolding of the complexity was not only necessary, but also afforded a peculiarly thrilling intellectual challenge to the attorney seeking a just result.

The relation between a judge's own morality and that of his society has been acutely presented by reactions to Judge Devlin's book, The Enforcement of Morals.FN54 The book reveals a judicial attitude not unlike Fuller's description of the judge on a desert island. Devlin argues that despite signs of change in England, the common man (at the time of his writing, 1959) still regards homosexuality as a punishable crime. Thus, Devlin concludes, a judge such as himself ought to enforce the statutory laws against homosexuals even though he, as judge, may not personally share the abhorrence of the "man on the Clapham omnibus" for homosexuality.FN55 I find this to be a most [pg217] remarkable statement about the role of a judge, particularly Devlin's feelings that a judge ought to decide cases in conformity with general popular attitudes. Would he throw the book at two homosexuals who acted in the privacy of their own home, even if he himself believed that what they were doing was not particularly bad or harmful? What compulsion exists in Devlin's mind for him to decide the case that way? Does he view himself as a mere instrument of majority feelings? If so, then on the desert island he would presumably not hesitate to order the execution of the two homosexuals. But what I cannot understand is, what is the nature of the "morality" that seems to urge Judge Devlin to conform his judgments to community preferences, particularly when he admits that the community on this matter is unenlightened? A year later if a poll indicates that $51 \%$ of the British public believes that homosexuality should be decriminalized, would Judge Devlin suddenly begin throwing homosexuality cases out of court? According to his book, the answer would eventually be in the affirmative.FN56 Note the way Fuller himself handles the homosexuality question, after citing Devlin in a footnote. Fuller says he personally would decriminalize homosexual behavior among consenting adults because "any such law simply cannot be enforced and its existence on the books would constitute an open invitation to blackmail, so that there would be a gaping discrepancy between the law as written and its enforcement in practice."FN57 But this hardly solves the problem of what a judge should decide. Is Fuller simply saying why he would decriminalize homosexuality if he were a legislator? Or is he saying what a judge-like the judge in my hypothetical based on Fuller's desert island — ought to decide? If he is talking about what a judge should decide, then it would appear to be open to the judge to say, "I don't accept Fuller's conclusion because it is not consistent with his own premises, which include as an internal morality of law the requirement 
of congruence between official action and declared rule. By enforcing the statute against homosexuality to its letter, I will be acting in accordance with Fuller's admonition. My job is to narrow the gap between the letter of the law and its enforcement, as Fuller says in the main part of his book, and not to widen that gap, as Fuller says in his personal comment later in the same book about what he [pg218] would do about homosexuality. Therefore I will regard his personal comment as an inconsistent departure from his own thesis."

I hope I have succeeded in suggesting some of the important ways in which Fuller can be criticized from the right. Because Fuller explicitly uses and repeats the terms "morality" and "Natural law," he invites this kind of criticism. I do not criticize Fuller for not moving his own philosophy farther to the right, but I think there is a kind of relativism that permeates his work that causes it to sit uneasily just to the right of center on the spectrum that I have drawn up. To my mind, Fuller was at his best when criticizing and attacking positivism and legal realism; he suggested that there were vast new ways of looking at legal questions. But when he spelled out his own viewpoint, I am less satisfied with the vision that he has left us. He seems to want a philosophy that is based on morality but he also wants one that is neutral. His "procedural morality" is, I think, very enlightening as far as it goes, but it seems incomplete for the reasons I have tried to in here. And its incompleteness, I am forced to conclude, is not simply that Fuller did not extend his own views far enough, but rather, in his attempt to ground his philosophy in morality and natural law, that he went too far in trying to label a relativistic and utilitarian system as "morality"—despite his use of the qualifying adjectives "procedural" and "inner."

\section{Footnotes}

*1981 Anthony D'Amato. This essay is a slightly revised version of a paper read at the Jurisprudence Section of the annual meeting of the American Association of Law Schools, San Antonio, Texas, January 3, 1981.

**Numbers in the format "pg202” etc. refer to the pagination of the original article.

FN1. Fuller, "Positivism and Fidelity to Law_A Reply to Professor Hart," 71 Harv. L. Rev. (1958), p. 630, 639-40.

FN2. See J. Bentham, "A Fragment on Government," in 1 Works (Bowring ed. 1859), p. 221, 230, 287-88; Bentham, Of Laws in General (Hart ed. 1970), p. 191.

FN3. See H.L.A. Hart, The Concept of Law (1961), p. 181.

FN4. See R. Dworkin, Taking Rights Seriously (1977), p. 22.

FN5. See ibid., p. 240-78.

FN6. See Fuller, supra n. 1, at p. 636; L.L. Fuller, The Morality of Law (rev. ed. 1969).

FN7. See Cicero, De Legibus II. v. 11-13. 
FN8. Ibid., p. 13.

FN9. See L.L. Fuller, The Law in Quest of Itself (1940), p. 27-38, 67-77.

FN10. See, e.g., A. Einstein \& L. Infeld, The Evolution of Physics (1938), p.177-79.

FN11. See, e.g., R. Benedict, Patterns of Culture (1934); C. Kluckhorn \& H.A. Murray, Personality in Nature, Society and Culture (1949); M. Mead, Coming of Age in Samoa (1928).

FN12. See Wechsler, "Toward Neutral Principles of Constitutional Law," 73 Harv. L. Rev. (1959), p. 1; A.M. Bickel, The Least Dangerous Branch (1962), p. 49-65.

FN13. R. Benedict, supra n. 11, at 52-119.

FN14. M. Mead, Coming of Age in Samoa (1928).

FN15. An anthropologist recently wrote a book about the Ik community in the mountains separating Uganda and Kenya, and described mothers who would abandon their three-year old children in the fields and hope that a predator would come along and carry them off-one did when the anthropologist was there "and the mother was delighted." C. M. Turnbull, The Mountain People (1972), p. 136. The author describes a father who laughed when his ten-yearold son developed an intestinal blockage, and joked about the distended belly. The author offered to drive the boy to a hospital, but the father stalled and wanted to go instead (to get a ride in the Land Rover). The father stole food from the boy, and the boy finally died. Ibid., p. 218-19. The reason this book attracted unusual interest was in part because its author stated his disapproval of these sorts of practices among the Ik. Shockingly, an anthropologist was passing judgment upon the subjects of his study! In our terms, the author refused to make M-l into M-2.

FN16. W. K. Frankena, Ethics (2d ed. 1973), p. 24-25.

FN17. Benedict, "Anthropology and the Abnormal," in D. Haring (ed.), Personal Character and Cultural Milieu, p. 195.

FN18. R. Benedict, supra n. 11.

FN19. John W. Cook, unpublished manuscripts and notes on moral relativism (Professor Cook may be contacted through the journal Philosophical Investigations).

FN20. Rousseau's attempt to reconcile democracy and natural law, in his Social Contract, has totalitarian overtones. See J. Plamenatz, 1 Man and Society (1963), p. 433-36. The American experiment, in contrast, has a Bill of Rights that is a protection against majority will. See R. Dworkin, supra n. 4, at p. 184-97.

FN21. Cicero, De Legibus II. v. 13. 
FN22. H.L.A. Hart, supra n. 3, at p. 6, 22.

FN23. Cicero, De Legibus II. iv. 10.

FN24. L.L. Fuller, The Morality of Law (rev. ed. 1969), p.39. Professor Moffat takes issue with my analysis here. See Moffat, Lon Fuller: Natural Lawyer After All! 26 Am. J. Juris. p. 190, n. 30 (1981). First, he says there is considerable irony in my accusing Fuller of refusing to accept morality as law. I plead guilty to this charge, though I am not trying to achieve irony but merely to function as an objective critic. Second, he says that Fuller would want mentioned the point that the internal morality of law is largely a morality of aspiration rather than a morality of duty. Here again, I agree; but the difficulty is reconciling the "morality of aspiration" with what we normally mean by "law." The law comes to us in the form of duties, powers and entitlements. It is not the law itself that is aspiring to do more than communicate to us these powers and entitlements, though the laws may reflect, in relatively "good" societies, such an aspiration. I agree with Fuller that we ought to interpret the law as if it reflects such an aspiration. But aspiring to be good is different from doing what is right, and as long as Fuller himself made the distinction, it seems rather weak to contend (a) that there is an internal morality of law, and (b) that what we mean by this "morality" is not the morality we are accustomed to, that tells us what to do, but a different kind of morality, that tells us what we ought to aspire to do. Third and finally, Professor Moffat says that glitches in the law may he cured by retrospective statutes. In this he is again correct that Fuller advocated such an approach. I feel that Fuller either made a big mistake in so doing, or if he did not make a mistake, then even under his own philosophy the cure seems worse than the disease. This particular point is something that I have previously dealt with at length. See D'Amato, "The Limits of Legal Realism," 87 Yale L.J., pp.468, 506-13 (1978).

FN25. See L.L. Fuller, Anatomy of the Law (1968), p. 133-74. See generally K.I. Winston, The Principles of Social Order (1981).

FN26. See B. Weston, R. Falk, \& A. D'Amato, International Law and World Order (1980), p.141, 102-15.

FN27. See D'Amato, "The Limits of Legal Realism;”87 Yale L.J. (1978), p. 468, 506-13.

FN28. 59 Harv. L. Rev. (1946), p. 376.

FN29. His other favorite, as he told me, was Fuller, "Human Interaction and the Law," 14 Am. J. Juris. (1969), p. 1, reprinted in R.P. Wolff (ed.), The Rule of Law (1971), p. 171.

FN30. J. Rawls, A Theory of Justice (1971), p. 17-22.

FN31. Fuller, supra n. 28, at p. 379.

FN32. Ibid. 
FN33. In setting up this hypothetical, I have in mind two anecdotal pieces of information that have come my way. The first is that on a particular ship in the United States Navy, two men were seen engaging in homosexual acts. The next morning, when the roll was called, the names of the two men were omitted from roll-call. No one aboard the ship ever saw or heard from them again. The person telling me this story, who was aboard the ship at the time, said that it was common knowledge that homosexuals would be dealt with in that fashion. The second story was reported by Professor Jerome Cohen of Harvard Law School after one of his Rosenthal Lectures at Northwestern Law School a few years ago. In response to my question, he stated in an informal gathering of faculty and students that in visiting two different communities in mainland China, he heard that persons found to be engaging in homosexual acts were taken away and summarily executed.

FN34. L.L. Fuller, supra n. 24, at p. 33-94. Professor Moffat, op. cit. supra n. 24, at n. 35, reminds us that Fuller's relativism may have reflected his suspicion of code-like substantive natural law principles. Clearly, Fuller was suspicious of Divine dictates of morality; commands from God were likely to be no better than commands from Austin's sovereign, and indeed worse if they appeared to be conclusive on the issue of what morality requires. I think Fuller's fear of code-like moral absolutes derived from two influences in his life. First, they derived from the criticism his colleagues constantly levelled at him, that in his espousal of "natural law" he was justifying a moral absolute position which was no different from the way the Nazis viewed their Aryan philosophy. Second, I think Fuller took St. Thomas Aquinas too seriously. Aquinas attempted to prove (in fact he probably felt that he had to prove) that the law of God was the same in content as natural law. But Aquinas also regarded the law of God as consisting of commands (much like the commands of a sovereign). Part of this conception of law-ascommand found its way into Aquinas' concept of natural law. I believe that Fuller, as he studied Aquinas, also came to believe that substantive natural law requires code-like rigidity. He veered away from that and hence moved (mistakenly as I have tried to show) toward relativism. But that move, in my judgment, was not required. Instead, he could have attempted to separate out the heart of Aquinas' theory of natural law as right reason from the more polemically inspired attempt of Aquinas to equate natural law with Divine law, and also (with more difficulty) he could have separated from Aquinas' discussion of natural law Aquinas' own law-as-command bias derived undoubtedly from a contemplation of Divine law. In the present essay, I have tried to summarize these matters by placing Aquinas on my chart to the left of Cicero. I think Cicero (of whom Fuller was of course familiar, though later in Fuller's life he seemed to read and reread Aquinas rather than Cicero) is a better exemplar of substantive natural law. Yet Cicero's works are less analytical than Aquinas' and hence Fuller was influenced more than I think he needed to be with Aquinas' slightly positivist (i.e., command-type) version of natural law.

FN35. Opinion of Chase, J., in Calder v. Bull, 3 U.S. (3 Dall.) 386 (1798).

FN36. See D'Amato, The Speluncean Explorers-Further Proceedings, 32 Stan. L. Rev. (1980), p. 467, 481.

FN37. See, e.g., B.A. Ackerman, Social Justice in the Liberal State (1980). 
FN38. Despite Rawls' attack on utilitarianism in his A Theory of Justice, supra n. 30, at p. 2227, Rawls prescriptions seem to be contained within discrete states and not easily shifted internationally, thus raising the question whether his system as well might change content as it crosses national boundaries. See D'Amato, "International Law and Rawls' Theory of Justice," 5 Denver J. Int'l L. \& Policy (1975), p. 525.

FN39. This is part of the problem in St. Thomas Aquinas' view of natural law. By considering it a system in parallel with other legal regimes, Aquinas comes out more positivistically than he is sometimes regarded. See Aquinas, Summa Theologica, Ia-2ae. xci. \& ff.

FN40. R.M. Cover, Justice Accused (1975).

FN41. Ibid., p. 8-19. This simplistic equation occurs despite the author's own admonition (at p. 8-9) that the issue may be complex. In the next paragraph in the text, I suggest parenthetically that the natural-law position regarding slavery might have something to do with how the situation arose and is maintained. Would natural law forbid slavery if it were the only way a head of a household could raise enough money to save his family from starvation and send them to another country? Compare Kronman, "Wealth Maximization as a Normative Principle," 9 J. Legal Studies (1980), p. 227, 241. By focusing upon the operative principles of slavery, especially its effect outside the control of the "owner," as is suggested in the text, one might get a better handle on the legal analysis.

FN42. R.M. Cover, supra n. 40, at p. 9, 17,21; "natural law tradition was more important for what it said about law than for what it said as law," at p. 19.

FN43. Ibid., p. 257-59.

FN44. See, e.g., Prigg v. Pennsylvania, 41 U.S. (16 Pet.) 539 (1842).

FN45. See, e.g., Jones v. Van Zandt, 46 U.S. (5 How.) 215 (1847).

FN46. Compare H. L. A. Hart, The Concept of Law (1961), p. 205-07.

FN47. R. M. Cover, supra n. 40, at p. 226-29.

FN48. Ibid., p. 25-28, 226, 257.

FN49. Ibid., p. 29-30.

FN50. See Hart, "Positivism and the Separation of Law and Morals," 71 Harv. L. Rev. (1958), p. 90, 100. See also P. Nonet \& P. Selznick, Law and Society in Transition: Toward Responsive Law (1978), p. 46-52, 68-70.

FN51. See D'Amato, "Elmer's Rule: A Jurisprudential Dialogue," 60 Iowa L. Rev. (1975), p. 1129. 
FN52. R.M. Cover, supra n. 40, at p. 257.

FN53. For the purposes of illustration only, a possible use of the natural law approach in this situation might be, in a case involving the fugitive slave law, to construe strictly the language of the Act of February 12, 1793, Chap. 1 Stat. 302 (1793), which defines the slave-owner who may seize or arrest a fugitive, as "the person to whom such labour or service may be due." Under the analysis given in the text, there is no labor or service "due" to such a person since the slave has no such moral responsibility once having escaped from the owner. Hence the slave owner is not empowered under the Act. Of course, this interpretation arguably defeats the purpose of Congress, but who is to say definitively that some legislators did not want just this loophole to be exploited? More seriously, this interpretation would conflict with Fuller's own emphasis upon purpose for statutory interpretation, a conflict that has been explored with other examples in the text.

FN54. See P. Devlin, The Enforcement of Morals (1965); H.L. Packer, The Limits of the Criminal Sanction (1968); R. Dworkin, supra n.4, at p. 240-58.

FN55. P. Devlin, supra n. 54, at p. 15.

FN56. Devlin would wait a while lest the law give the impression that moral judgment is being weakened, ibid., p. 18. This is clearly a non sequitur, as Devlin had just finished assuming that the moral standard (e.g., on homosexuality) had changed.

FN57. L.L. Fuller, supra n. 24, at p. 133. 